\title{
THE EFFECT OF LEADERSHIP, CULTURAL WORK AND MOTIVATION ON PERFORMANCE OF FIELD AGRICULTURAL EXTENSION WORKERS (Study at Agriculture Service of Bondowoso Regency)
}

\author{
Kusmiati $^{1}$ \\ Bagus P. Yudhia ${ }^{2}$ \\ Zainollah $^{3}$ \\ Higher Education of Economic Mandala \\ e-mail: Memeyflower1616@gmail.com
}

\begin{abstract}
This research was conducted with the purpose of knowing and analyzing the leadership, cultural work and motivation which have a significant effect on the Performance of Field Agricultural Extension in Agriculture Service of Bondowoso regency partially and simultaneously and to know the dominant variable influencing the performance of Field Agricultural Extension in Agriculture Service of Bondowoso regency. The object of this research is Field Agricultural Extension in Agriculture Service of Bondowoso regency which is 69 people. This research uses quantitative research. As an independent variable namely leadership (X1), work culture (X2) and motivation (X3) and the dependent variable is Performance (Y). Data analysis used is validity and reliability test, multiple regression assumption test, and multiple linear regression analysis.

The results showed that leadership, work culture had a significant partial effect while motivation did not have a significant partial effect, leadership, work culture and motivation simultaneously had a significant effect on the performance of field agriculture instructors. With the largest leadership regression coefficient, it can be concluded that the leadership variable has a dominant influence on the performance of field agricultural extension workers. The result of the determination coefficient (R2) is $0.662(66.2 \%)$. So the performance of field agricultural extension workers in the Agriculture Service of Bondowoso regency is influenced by the three independent variables at $66.2 \%$ while the remaining $33.8 \%$ is influenced by other variables outside the research
\end{abstract}

Keywords: Leadership, Work Culture, Motivation, Performance

\section{INTRODUCTION}

The current era of globalization demands a high performance of Agricultural Field Extension for the development of an organization. Every organization must be able to improve performance in its environment. The success of an organization is influenced by several factors, one of which is human resources because it is the driving force of all levels from planning to evaluation by utilizing other resources owned by the organization.

The performance of the Field Agriculture Extension Team determines the results to be achieved by an agency. The maximum performance of the Agricultural Extension Field will produce maximum results as well. However, often 
the Field Agricultural Extension Workers who do not work optimally are influenced by several factors, thus preventing the Agricultural Field Extension to perform optimally. According to Mas'ud (2004), performance is the achievement of the effort that has been done which can be measured by certain indicators (individual performance and organizational performance). Thus the problem of employee performance is also related to the problem of the ability of people to develop themselves in order to be able to work towards the goals desired by the organization. In discussing success or performance one needs to establish a certain measure to assess whether the organization has performance

In Law No. 16 of 2006 concerning the Agricultural, Fisheries and Forestry extension system, stated that the development of agriculture, fisheries and sustainable forestry is a must to meet the needs of food, shelter and industrial raw materials; expanding employment and field work; improving people's welfare, especially farmers, planters, breeders, fishermen, fish cultivators, fish processors, and communities in and around forest areas; alleviate people from poverty, especially in rural areas; increase national income; and safeguarding the environment; Whereas to further enhance the role of the agriculture, fisheries and forestry sectors, quality, reliable human resources and managerial, entrepreneurial, and business organization capabilities are needed so that the actors of agricultural, fishery and forestry development are able to build businesses from upstream to downstream that are empowered. highly competitive and able to participate in conserving forests and the environment in line with the principles of sustainable development. But in reality, not all extension workers have the skills, skills and morale as stated in the law. There are many factors that can affect performance, including: leadership, motivation, work environment, incentives, work culture, communication, agricultural extension counseling, training and many others. All of these factors must have influenced the dominant and some not. This can be understood because each individual instructor has a different educational background, experience, motivation, basic abilities, and other things, which ultimately affect their performance. Therefore the presence of a leader who is able to motivate, equate perception, unify vision and mission, is needed. Becoming a good leader needs to be filled with requirements that involve several aspects such as physicality, knowledge, skills, attitudes, and certain personalities. A leader must successfully manage the resources possessed in an organization, including in managing its human resources. The management of human resources in question is that must be able to unite the perceptions or perspectives of employees and leaders to achieve goals, including a leader providing compensation, work motivation, direction and good coordination. In addition the leader must have a good leadership spirit towards the employee.

According to Rivai (2008), the definition of leadership broadly includes the process of influencing in determining organizational goals, motivating followers' behavior to achieve goals, influencing to improve their groups and culture. Besides that it also influences the interpretation of the events of his followers, organizing and activities to achieve goals, maintaining cooperative relationships and group work, obtaining support and cooperation from people outside the group or organization.

Field Agriculture Extension (PPL) as a development communicator is expected to be able to do multitasking, as 
agricultural extension, mentor, advisor, information delivery and the farmer's partner. Therefore, improving the performance of PPL is very important in maintaining the continuity of extension programs at the field level. This is closely related to motivation and job satisfaction that can be obtained by agricultural extension workers. Some studies of extension workers suggest that their performance is relatively low. According to Widiyati (2000), motivated workers will use $80-90 \%$ of their ability to work (in average). And those who are not motivated only use $20-30 \%$ of their ability to work.

According to Herzberg's two-factor theory in Stoner and Freeman (1992), there are two factors that influence a person's motivation at work: First is the intrinsic factor which includes elements of achievement, recognition, work, and responsibilities; Second are extrinsic factors including administration and policy, supervision, salaries and rewards, interpersonal relationships, working conditions and status. A person's motivation in work has to do with job satisfaction and work productivity. Job satisfaction is influenced by psychological, social, physical, and financial factors. While work productivity is influenced by education and training, skills, technology, work environment, work discipline, and remuneration received.

Work culture can be formed from a routine when working. A work culture can be used to bind employees through formal or unwritten rules. By standardizing work culture, as a reference for the applicable rules or regulations, the leaders and employees will indirectly be bound so that they can form attitudes and behavior in accordance with the vision / mission and strategy of the company / school. The formation process will ultimately produce professional leaders and employees who have high integrity. Budi Paramita (Taliziduhu Ndraha, 2005: 208), argues that work culture as a group of basic thoughts or mental programs that can be used to improve work efficiency and human cooperation owned by a group of people. Gering and Tri (2001: 7) argue that work culture is a philosophy based on the view of life as values that become the nature, habits and also the drivers that are cultivated in a group and reflected in the attitude to behavior, ideals, opinions, views and actions that manifest as work.

Many ways are carried out by the agency in an effort to improve the performance of its Agricultural Extension Field Workers, for example by paying attention to whether there is motivation within the Field Agricultural Extension Worker, the Field Agricultural Extension job satisfaction and its supportive work environment. Motivating the Field Agricultural Extension worker is one of the leaders duties. It is not only they have to know how to grow motivation in general, but they also have to be able to invite the Field Agricultural Extension how to grow the motivation in order to be able to apply it. According to Sutrisno (2011), motivation is a factor that encourages a person to do a certain activity, therefore motivation is often interpreted as a driving factor for a person's behavior. Every activity carried out by a person must have a factor that drives the activity.

The phenomenon that becomes a problem in the Agriculture Service is that not all Field Agricultural Extension Workers have the expected performance, both in quality, quantity and efficiency of their working time in realizing the vision and mission itself. Firm leadership is also not enough to improve the performance of this unit. This can be seen when there are new leaders who also change policies so that it will affect the performance of the 
worker/instructor. Some extension workers have shown good performance along with the change of leadership, but there are also those whose performance is not as expected, the lack of timely agricultural extension workers in completing work and so on indicates the performance of the agricultural extension worker is not yet optimal. In addition, there is an impetus that is less than in the Agricultural Extension Field that will have an impact on its performance. This is related to the lack of motivation of the Field Agricultural Extension and there is also a high motivation both inside and outside of the Field Agricultural Extension itself, so that the performance of the Field Agricultural Extension worker who has less motivation will decrease. These three factors have a greater influence on the performance of the Field Agricultural Extension on Agriculture Service unit compared to other factors such as commitment, work environment and so on.

Based on the research gap and the phenomena that have been described, this study discusses the influence of leadership, work culture and motivation on the performance of the Field Agricultural Extension of the Agriculture Service unit of Bondowoso Regency.

From the background of the problem, it can be compiled the formulation of the problem in this study, namely: (1) Does leadership, work culture and motivation have a significant partial effect on the performance of Field Agricultural Extension Workers at the Agriculture Service of Bondowoso Regency? (2) Does leadership, work culture and motivation have a significant and simultaneous effect on the performance of the Field Agricultural Extension at the Agriculture Service of Bondowoso Regency? (3) Which is the dominant influence on the performance of the Field Agricultural Extension in the Agriculture Service of Bondowoso Regency?

Based on the formulation of the above problems, the general purpose of this research is: (1) to determine and analyze the significant influence of leadership, work culture and motivation partially on the performance of the Field Agricultural Extension at the Agriculture Service of Bondowoso regency, (2) to determine the influence and significant analysis of leadership, work culture and motivation simultaneously on the performance of the Field Agricultural Extension at the Agriculture Service of Bondowoso regency, (3) To find out the most dominant variables on the performance of the Field Agricultural Extension at the Agriculture Service of Bondowoso regency.

This research is expected to have the following uses: (1) to develop science and knowledge in the field of Human Resource management, so that it will be beneficial for the Master of Management program in the form of information and references in the field of educational institutions, (2) for the Agriculture Service it is useful to know how much difference the performance of agricultural extension workers which is related to the assessment of leadership, work culture, motivation and performance of Field Agricultural Extension workers, (3) for Field Agricultural Extension workers it can be used as a reference to improve the quality of performance.s

\section{Leadership}

Leadership is a way used by a leader in influencing the behavior of others. Leadership is a behavior norm used by someone when the person tries to influence the behavior of others. Each of these styles has advantages and 
disadvantages. A leader will use leadership according to his abilities and personality (Sukarno Marzuki, 2002).

The leadership review was conducted at the University of Michigan Research Center, with the aim: locating the characteristics of leadership behaviors that seem to be associated with a measure of performance effectiveness. Through research it is identified two different leadership, referred to as job-centered, task-oriented and employee-centered oriented towards people / employees. According to Hasibuan (2005), Leadership is: a. Authoritarian Leadership; b. Participatory Leadership; c. Delegative Leadership

\section{Work Culture}

Work culture is a philosophy based on a view of life that is coming from values that become traits, habits, and also the drivers that are cultivated in a group that is reflected in the attitude to behavior, ideals, opinions, views, and actions that manifest as work / workers (Gering, Supriyadi, and Triguno, 2001: 7). Budi Paramita (Taliziduhu Ndraha, 2005: 208), argues that work culture as a group of basic thoughts or mental programs that can be used to improve work efficiency and human cooperation owned by a group of people.

\section{Motivation}

According to Gibson (2007: 185), motivation is "The force that encourages a field agricultural extension worker who raises and directs behavior". In this case motivation can be concluded as a series of activities to provide encouragement not only to others but also to someone itself. From some understanding of motivation, it can be concluded that motivation is an impulse that arises and is able to move itself as a step to achieve the desired goal. From some definitions that have been described previously it can be explained that motivation can be measured through indicators, including: (1) job enrichment, (2) participation, (3) management results, (4) manager multiplier, (5) mind power, (6 ) realistic human relations, environment, (8) working hours, criticism.

\section{Performance}

Accoring to Rizky (2013), performance is the work of an employee or employee during a certain period compared to various possibilities, such as the target standard, target, or predetermined criteria and mutually agreed upon. If employees do not do their work, an organization will fail. Human behavior, level and quality of work are determined by a number of individual and environmental variables. According to Wibowo (2012), performance is about doing work and the results achieved from the job. Performance is about what is done and how to do it.

Based on this, a framework of thought can be arranged as follows:

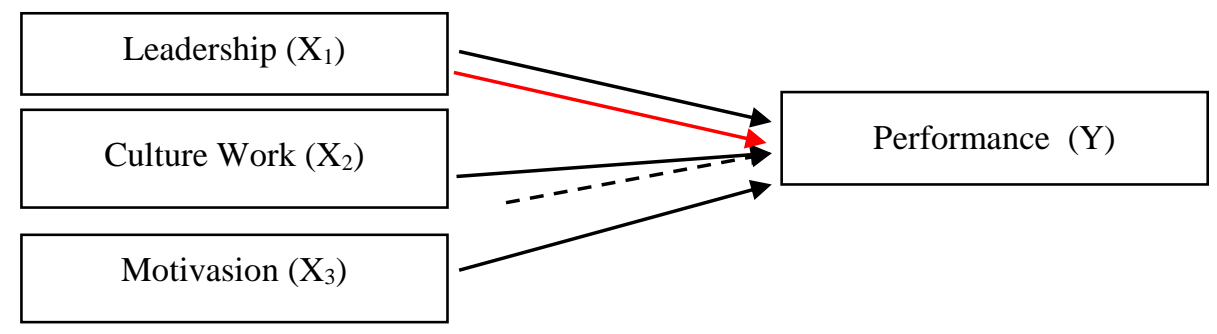


Information :

$$
\begin{aligned}
\longrightarrow & =\text { By partial } \\
----\longrightarrow & =\text { By simultaneous }
\end{aligned}
$$

Hypothesis

The research hypotheses are as follows: (1) Leadership, work culture and motivation have partial effect on the performance of Field Agricultural Extension Workers at the Agriculture Service of Bondowoso regency, (2) Leadership, work culture and motivation simultaneously influence the performance of Field Agricultural Extension Workers at the Agriculture Service of Bondowoso regency, (3) Leadership has a dominant influence on the performance of Field Agricultural Extension Workers at the Agriculture Service of Bondowoso regency

\section{RESEARCH METHODS}

This type of research is causality research. According to Ferdinand (2006), causality research is a study that seeks clarity and form of causal relationships between several concepts and several variables or several strategies developed in management. In this study the population was all civil servant agricultural extension workers who worked in the office of the Bondowoso Agriculture Service office, amounting to 69 employees. Determination of sampling is determined using saturated sampling techniques. Saturated sampling is a sample determination technique if all members of the population are used as samples. This is often done if the population is relatively small. Another term for saturated samples is a census. The reason for using this census method is to make the research more representative, so that the research is more objective. The population and sample in this study are the same, namely all PNS agricultural extension workers who work in the office of the Bondowoso Agriculture Service Office, totaling 69 employees. so that the census sample method is used (Total Sampling).

In this study primary and secondary data sources were obtained from: (1) primary sources were obtained directly from respondents, in this case the respondent in question was an employee of the Field Agricultural Extension office of Bondowoso regency. Data from primary sources in this study were obtained by giving questionnaires to respondents. Data from questionnaires will be analyzed later in this study, (2) secondary sources are obtained from the literature related to research and data from the office of the Agriculture office of Bondowoso Regency. Data collection methods used in the study are as follows: (1) Questionnaire (questionnaire) in the form of an open questionnaire filled by respondents.

\section{Research Variables and Operational Definition of Variables}

In this study there are five variables consisting of three variables $\mathrm{X}$ and one variable Y namely:

\section{Leadership (X1)}

Leadership is the process of influencing others, both within the organization and outside the organization to achieve the desired goals in certain situations and conditions (Rivai, 2008)

The indicator used consists of: 
a. Oriented to task completeness

b. Oriented to subordinates

2. Work Culture (X2)

Measurement indicators on work culture refer to the opinions of Ndraha (2005: 209) which in this study focused on attitudes and behavior

The indicator used consists of:

a. Assumption about work

b. Attitude towards work

c. Behavior at work

d. Environment and work tools

e. Work ethic

3. Motivation (X3)

Motivation is a concept that describes the strengths that exist in an individual to initiate and direct behavior (Gibson, Ivancevic and Donelly in Pupuh and Suryana, 2012)

The indicator used consists of:

a. Intrinsic

b. Extrinsic

4. Employee Performance (Y)

Performance is the achievement or achievement of a person with regard to the tasks assigned to him (Marwansyah, 2010).

The indicators used are:
a. Quantity
b. Quality
c. Punctuality

\section{Data analysis method}

Before processing further data, the questionnaire is tested first, which is testing the validity and reliability test. Measurement of validity and reliability is absolutely done, because if the instrument used is invalid and reliable, then the results of the research will not be valid and reliable.

\section{Validity Test}

Validity test is used to measure whether a questionnaire is valid or not. According to Sugiyono (2012: 121) "The instrument is said to be valid means showing the measuring instrument used to get the data valid. Valid means that the instrument can be used to measure what should be measured ". Validity test is done by calculating the correlation value (r) between scores on each question with a total score.

2. Reliability Test

Reliability test is a test to ascertain whether the research questionnaire will be used to collect reliable research variables or not. The questionnaire is said to be reliable if the questionnaire is repeated, it will get the same results. The reliability test is done by calculating Spearman Brown.

\section{Assumption Test of Multiple Linear Regression}

Assumption test of multiple linear regression is a test that is used to avoid any deviation from the basic assumptions of the linear regression function used. (Santoso, 2001). The use of regression analysis as an analytical model must meet the classical assumptions so that a linear estimator is not biased or accurate. The classical assumptions tested in this study for the fulfillment of unbiased estimators consist of normality, linearity and heteroscedasticity.

\section{ANALYSIS AND DISCUSSION Validity and Reliability Test Analysis \\ 1. Validity Test}

The results of the validity test show that all question items are significantly correlated with indicators, and the indicators also correlate significantly with variables, indicated by the value of r count> r table. Significant correlation between items and indicators shows that the items used can measure indicators, while indicators are significantly correlated with variables indicating that the indicators used are able to measure the variables studied, the instruments used are able to measure the variables studied so that all question items are declared valid.

2. Test Reliability 
The reliability test results obtained reliability coefficient values greater than 0.6. In accordance with the opinion (Nurgiyantoro, 2000) that the question is declared reliable (reliable) if the Cronbach Alpha value is greater than 0.6. So it can be stated that all statements in the questionnaire are reliable.

\section{Classical Assumption Test Results}

1. Normality Test

This normality test aims to find out whether in the regression model proposed in the study, the residual variable is normally distributed or not.

Table 4.1

Normality test results

One-Sample Kolmogorov-Smirnov Test

\begin{tabular}{|c|c|c|c|c|c|}
\hline & & $\begin{array}{l}\text { Kepemim } \\
\text { pinan }\end{array}$ & Buday a & Motiv asi & Kinerja \\
\hline $\mathrm{N}$ & & 69 & 69 & 69 & 69 \\
\hline \multirow[t]{2}{*}{ Normal Parameters a,b } & Mean & 39,80 & 39,04 & 39,86 & 39,12 \\
\hline & Std. Deviation & 4,507 & 5,242 & 4,099 & 6,857 \\
\hline Most Extreme & Absolute & , 127 & , 105 & , 128 & 161 \\
\hline \multirow[t]{2}{*}{ Differences } & Positive &, 055 &, 063 & ,062 & 096 \\
\hline & Negative &,- 127 &,- 105 &,- 128 &,- 161 \\
\hline Kolmogorov-Smirnov Z & & 1,052 & , 875 & 1,059 & 1,341 \\
\hline Asymp. Sig. (2-tailed) & & ,218 & ,428 & ,212 & 055 \\
\hline
\end{tabular}

a. Test distribution is Normal.

b. Calculated from data.

Source: Primary data, 2017

In Kolmogorov-Smirnov test above, it can be seen that the significance of all variables is above the $\alpha$ (standard error) of 0.05 where leadership variables have a significance value of 0.218 (above 0.05 ), work culture variables of 0.428 (above 0.05), Variable of motivation equal to 0,212 (above 0,05), and performance variable equal to 0,055 (above 0,05) This proves that data from variables under study have normal distribution and can be continued for other test

2. Linearity Test

Linearity test aims to determine whether two variables have a linear or not significant relationship

Table 4.2

Linearity Test

ANOVA Table

\begin{tabular}{|c|c|c|c|c|c|c|c|}
\hline & & & $\begin{array}{l}\text { Sum of } \\
\text { Squares }\end{array}$ & $\mathrm{df}$ & Mean Square & $\mathrm{F}$ & Sig. \\
\hline \multirow[t]{5}{*}{ Kinerja * Kepemimpinan } & Between & (Combined) & 2450,514 & 18 & 136,140 & 9,118 &, 000 \\
\hline & Groups & Linearity & 2023,173 & 1 & 2023,173 & 135,500 &, 000 \\
\hline & & Deviation from Linearity & 427,341 & 17 & 25,138 & 1,684 & ,078 \\
\hline & Within Groups & & 746,558 & 50 & 14,931 & & \\
\hline & Total & & 3197,072 & 68 & & & \\
\hline
\end{tabular}




\begin{tabular}{|c|c|c|c|c|c|c|c|}
\hline \multicolumn{8}{|c|}{ ANOVA Table } \\
\hline & & & $\begin{array}{l}\text { Sum of } \\
\text { Squares }\end{array}$ & $\mathrm{df}$ & Mean Square & $\mathrm{F}$ & Sig. \\
\hline \multirow[t]{5}{*}{ Kinerja * Buday a } & Between & (Combined) & 2061,265 & 20 & 103,063 & 4,356 &, 000 \\
\hline & Groups & Linearity & 1713,793 & 1 & 1713,793 & 72,426 & ,000 \\
\hline & & Deviation from Linearity & 347,473 & 19 & 18,288 & ,773 & ,725 \\
\hline & Within Groups & & 1135,807 & 48 & 23,663 & & \\
\hline & Total & & 3197,072 & 68 & & & \\
\hline
\end{tabular}

\begin{tabular}{|c|c|c|c|c|c|c|c|}
\hline \multicolumn{8}{|c|}{ ANOVA Table } \\
\hline & & & $\begin{array}{l}\text { Sum of } \\
\text { Squares }\end{array}$ & df & Mean Square & $\mathrm{F}$ & Sig. \\
\hline \multirow[t]{5}{*}{ Kinerja * Motiv asi } & Between & (Combined) & 1475,276 & 17 & 86,781 & 2,570 &, 005 \\
\hline & Groups & Linearity & 742,667 & 1 & 742,667 & 21,998 & , 000 \\
\hline & & Deviation from Linearity & 732,609 & 16 & 45,788 & 1,356 & ,202 \\
\hline & Within Groups & & 1721,796 & 51 & 33,761 & & \\
\hline & Total & & 3197,072 & 68 & & & \\
\hline
\end{tabular}

Source: Primary data, 2017

From the above output table, the value of significance $=0.078$, 0.725 and 0.202 is greater than 0.05 , because the significance is greater than 0.05 it can be concluded that between the variables of leadership, work culture, motivation and performance there is a significant linear relationship

3. Heteroscedasticity
Heteroscedasticity means the presence of unequal residual variation for all observations, or the presence of increasing residual variation in larger numbers of observations. The linear regression model assumes that the residual variant is constant or equal for various observations.

Table 4.3

Heteroscedasticity Result

\section{Scatterplot}

\section{Dependent Variable: Kinerja}

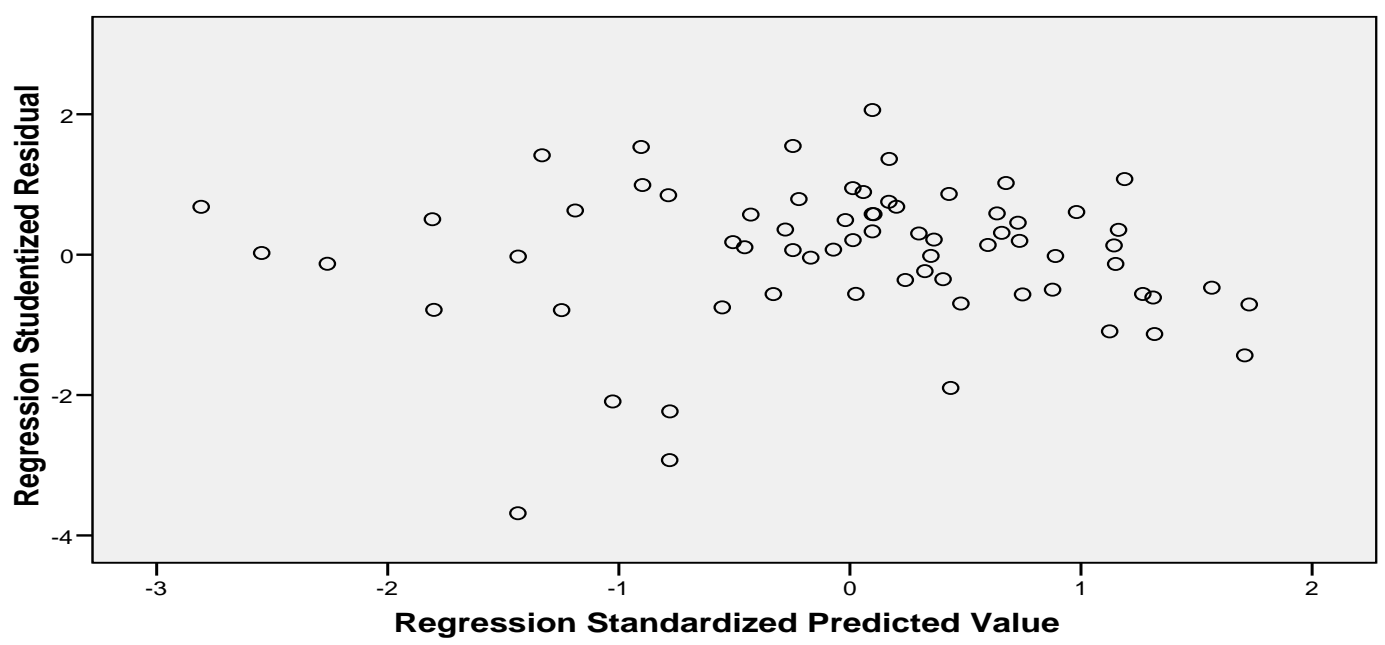

Source: Primary data, 2017 
From the above output it can be seen that the dots do not form a clear pattern, and the spots spread above and below the number 0 on the $\mathrm{Y}$ axis. So it can be concluded that there is no problem of heteroscedasticity in the regression model.
To find out how much influence of independent variables are variables of leadership variable, work culture and motivation to employee performance, Multiple Linear Regression Analysis is used. The calculation results using SPSS are as follows:

\section{Multiple Linear Regression Analysis}

Tabel 4.4

Coefficients(a)

Coefficients $^{a}$

\begin{tabular}{|c|c|c|c|c|c|c|c|c|}
\hline \multirow{2}{*}{\multicolumn{2}{|c|}{ Model }} & \multicolumn{2}{|c|}{$\begin{array}{l}\text { Unstandardized } \\
\text { Coef ficients }\end{array}$} & \multirow{2}{*}{$\begin{array}{c}\text { Standardized } \\
\text { Coef ficients } \\
\text { Beta }\end{array}$} & \multirow[b]{2}{*}{$\mathrm{t}$} & \multirow[b]{2}{*}{ Sig. } & \multicolumn{2}{|c|}{ Collinearity Statistics } \\
\hline & & $\mathrm{B}$ & Std. Error & & & & Tolerance & VIF \\
\hline \multirow[t]{4}{*}{1} & (Constant) & $-5,277$ & 5,156 & & $-1,023$ &, 310 & & \\
\hline & Kepemimpinan &, 979 & ,200 & ,644 & 4,890 &, 000 & , 301 & 3,327 \\
\hline & Buday a & ,398 & , 179 & , 304 & 2,222 &, 030 & 278 & 3,599 \\
\hline & Motiv asi &,- 254 &, 171 &,- 152 & $-1,485$ & , 142 &, 500 & 2,002 \\
\hline
\end{tabular}

Source: Primary data, 2017

$$
Y=-5,277+0,979 \times 1+0,398 \times 2-0,254 \times 3
$$

From the above equation it is known how the influence of leadership variables, work culture and motivation on employee performance. The positive coefficient value $(+)$ will show that the variable $\mathrm{Y}$ will change with changes proportional to the independent variable. While the coefficient with a negative sign (-) will indicate that the change in variable $\mathrm{Y}$ will be inversely proportional to the change in the independent variable.

Table 4.5

\section{Hypothesis testing}

1. Hypothesis 1 (Test Statistic t)

Test $t$ (Partial) in this research is used to know the influence of independent variable consisting of consist of leadership, work culture and motivation partially to employee performance. Table for df value of 65 with significant $5 \%$ is 2.00

Hypothesis Decision:

Partial Regression Calculation Result

\begin{tabular}{|c|c|c|c|c|c|}
\hline \multicolumn{5}{|c|}{ Variabel Dependen : Kinerja } & \\
\hline Variabel Independen & t- Statistic & t-tabel & Prob & Information & Hypothesis \\
\hline Kepemimpinan & 4,890 & \multirow{3}{*}{ $\pm 2,00$} & 0,000 & significant & diterima \\
\hline Budaya Kerja & 2,222 & & 0,030 & significant & diterima \\
\hline Motivasi & $-1,485$ & & 0,142 & Tidak significant & Ditolak \\
\hline
\end{tabular}

Source: Primary data, 2017

a. The Influence of Leadership on Performance

Based on the test results, it is obtained t-statistic results for leadership variables of 4.890 while the value of t-table of 2.00 . Therefore the value of tcount is bigger than ttable $(4,890>2,00)$, it can be concluded that partially the leadership variable has a significant effect on employee performance, so the findings of this study support hypothesis 1 
b. The Influence of Work Culture on Performance

Based on the test results, it is obtained t-statistic results for work culture variables of 2.222 while the value of t-table of 2.00. Therefore the value of tcount is bigger than ttable $(2,222>2,00)$, hence can be concluded that partially work culture variable have significant effect to employee performance, so findings of this research result support hypothesis 1

c. Effect of Motivation on Performance

Based on the test results, it is obtained t-statistic for motivation variable of -1.485 while the value of ttable of 2.00. Therefore, the value of tcount is greater than at -ttabel $(-2,00$ $<-1,485<2.00)$, it can be concluded that the partial variable of motivation does not affect the performance of employees, so the findings of this study do not support hypothesis 1

2. Hypothesis 2 (Test Statistic F)

Statistical test $\mathrm{F}$ in this study to show whether the variables consisting of the level of education, training, motivation and work culture have a simultaneous influence on employee performance. Anova test results (analysis of variance) can be presented in the following table:

Table 4.6

Result of the Analysis of Variants (ANOVA)

ANOVA $^{\mathbf{b}}$

\begin{tabular}{|ll|r|r|r|r|r|}
\hline Model & & Sum of & & & & \\
\hline 1 & Squares & df & Mean Square & F & Sig. \\
& Regression & 2115,169 & 3 & 705,056 & 42,359 & \\
& Residual & 1081,903 & 65 & 16,645 & & \\
& Total & 3197,072 & 68 & & & \\
\hline
\end{tabular}

a. Predictors: (Constant), Motivasi, Kepemimpinan, Buday a

b. Dependent Variable: Kinerja

Source: Primary data, 2017

Based on the calculation, the obtained value of f-count of 42.359 while the ftabel of 2.75. Because fhitung is bigger than f-tabel (42,359> 2,75) hence there is influence simultaneously between leadership variable, work culture and motivation to dependent variable that is employee performance. In addition, the probability of fcount (Sig. F Change) is 0.000 . Because the probability value fhitung below the value of 0.05 it can be concluded that the independent variables have an influence on the dependent variable. So the hypothesis stating that leadership, work culture and motivation simultaneously affect the performance of Field Agricultural Extension Workers at the Agricultural Service of Bondowoso regency proved true

\section{Hypothesis 3}

Hypothesis test in this research to show the dominant influence variable to the performance of Field Agricultural Extension Workers at the Agricultural Service of Bondowoso regency by looking at the independent variable which has the largest beta value (regression coefficient)

Based on the calculation results, the highest value of leadership regression coefficient is 0.979 , it can be concluded that leadership variable (X1) has a dominant effect on employee performance. Thus, $\mathrm{Ho}$ is rejected and $\mathrm{Ha}$ accepted, so the findings of this study support hypothesis 3

4. Coefficient of Determination

Based on the test results from 
the SPSS program, obtained the results of the coefficient of determination (R2) of $0.662(66.2 \%)$. The value indicates that the percentage of influence that can be caused by independent variable that is leadership, work culture and motivation to dependent variable is employee performance. So the performance of Field Agricultural Extension Workers at the Agricultural Service of Bondowoso regency which influenced by three independent variable is equal to $66,2 \%$ while the rest that is equal to $33,8 \%$ influenced by other variable outside research

\section{Interpretation of Research Results}

This study aims to analyze the influence of leadership, culture work and motivation on the performance of Field Agricultural Extension Workers at the Agricultural Service of Bondowoso regency.

1. The Influence of Leadership, Work Culture and Motivation on of Field Agricultural Extension Workers at the Agricultural Service of Bondowoso regency Partially

The regression coefficient of 0.979 leadership variable (X1) states that with the increase of leadership will improve employee performance in proportion to 0.979 , the regression coefficient of work culture variable (X2) of 0.398 states that with the improvement of work culture can improve performance comparable with 0.398, regression coefficient of motivation variable X3) of -0.254 states that with increased motivation can decrease performance is proportional to 0.254 .

a. Leadership

Based on the test conducted then it is obtained a picture that the leadership variable shows the results have a significant effect on employee performance. The results of this study indicate conformity with the theory of Rivai (2008) which states leadership is a process to influence other people, both within the organization and outside the organization to achieve the desired goals in a situation and certain conditions.

b. Culture Work

The result of regression coefficient test shows that culture work has significant effect to performance. Based on the results of these tests, it can be concluded that the second hypothesis that states work culture significant effect on proven performance. This means that if the work culture increases, it will improve the performance of Field Agricultural Extension Workers at the Agricultural Service of Bondowoso regency.

The results of this study indicate conformity with the theory of Gering, Supriyadi, and Triguno (2001: 7) which states that work culture is a philosophy based on a view of life based on the values that become the nature, habits, and also the drivers that are cultivated in a group that reflected in the attitude to behavior, ideals, opinions, views, and actions that manifest as work / workers.

3. Motivation

The result of regression coefficient test shows that motivation has no significant effect on performance. Based on the results of these tests, it can be concluded that the third hypothesis that states motivation has a significant effect on performance is not proven. This means that if the motivation increases, it will reduce the performance of Field Agricultural Extension Workers at the Agricultural Service of Bondowoso 
regency.

The results of this study indicate that it is not in accordance with the theories of Gibson, Ivancevic and Donelly (Pupuh and Suryana, 2012) which states that motivation is a concept that describes the forces within individuals to initiate and direct behavior

2. The Influence of Leadership, Work Culture and Motivation to Performance of of Field Agricultural Extension Workers at the Agricultural Service of Bondowoso regency Simultaneously

Based on the calculation, the fcount value is 42.359 while the f-tabel walue is 2.75 . Because f-count is bigger than f-tabel $(42,359>2,75)$ hence Ho is rejected and $\mathrm{Ha}$ accepted which states that there is influence simultaneously between independent variable which consist of leadership, work culture and motivation to dependent variable that is employee performance. In addition, the probability of f-count (Sig. F Change) is 0.000 . Because the probability value fhitung below the value of 0.05 it can be concluded that the independent variables have an influence on the dependent variable.

The phenomenon that becomes a problem at the Agriculture Service is not all Field Agricultural Extension has the performance as expected, both in quality, quantity and efficiency of work time in realizing the vision and mission itself. Firm leadership is also not enough to improve the performance of this unit. This can be seen when there is a new leader who also change the policies so that will affect the performance of extension workers. Some counselors have shown good performance along with the leadership replacement, but some are not performing as expected.
This is related to the lack of motivation of the Field Agricultural Extension and there is also a high motivation both inside and outside of the Field Agricultural Extension itself, so that the performance of the Field Agricultural Extension workers who has less motivation will decrease. These three factors have greater influence on the performance of the Field Agricultural Extension of the Agriculture Service Unit

\section{CONCLUSIONS AND SUGGESTIONS Conclusion}

Based on data analysis and discussion of research results, it can be concluded that

1. The first hypothesis which states that the variables of leadership, culture work and motivation have an influence on the performance of Field Agricultural Extension Workers at the Agricultural Service of Bondowoso regency partially. The three variables studied, leadership and culture work variables affect the performance because the value of tcount is greater than the $t$ table (2.00), while the motivation variable has no significant effect on the performance.

2. The second hypothesis which states that the variables of leadership, culture work and motivation have an influence on the performance of Field Agricultural Extension Workers at the Agricultural Service of Bondowoso regency simultaneously. All three variables have an effect simultaneously or together on achievement. It can be known by looking at the value of $\mathrm{f}$-count of 42.359 while the f-tabel of 2.75 . Because fcount is bigger than f-tabel $(42,359>2,75)$ hence can be concluded that variable of leadership variable, culture work and motivation have influence to employee performance variable simultaneoustly. 
3. The third hypothesis states that leadership variables have a dominant influence on the performance of Field Agricultural Extension Workers at the Agricultural Service of Bondowoso regency. Based on the calculation results, the highest value of leadership regression coefficient is 0.979 , it can be concluded that leadership variable (X1) has a dominant effect on employee performance

\section{Implications}

Based on the conclusion of the research results, it can be obtained the implications of this study. This research is not in accordance with theoretical and empirical foundation which states that motivation has a significant effect on performance, while in this study motivation has no significant effect on performance.

The final result of this research that is in order to improve performance, leadership and work culture also have to be improved, but for motivation to be lowered. This is in accordance with the concept of human resource development.

\section{Suggestion}

Based on the conclusion of the research results, it can be submitted some suggestions that are expected to be useful for practical interests and further interests.

1. Research finds that leadership has a significant effect on performance in a positive direction. Based on these findings, it is suggested to the Agriculture Service of Bondowoso regency to improve the performance of field agricultural extension workers by prioritizing the ability to complete the assigned tasks, then the second priority is reliable in work, the third priority is the ability to work together to overcome the work.

2. Research finds that work culture has a significant effect on performance with positive direction. Based on these findings, it is suggested to the
Agriculture Service of Bondowoso regency to improve the performance of field agricultural extension workers can be can be achieved by prioritizing the work culture of field agricultural extension workers to better overcome the work.

3. The study found that motivation had no significant effect on performance with negative direction. Therefore, it is suggested to the Agriculture Service of Bondowoso regency to increase the motivation of field agricultural extension workers to be increased intrinsic motivation and extrinsic motivation. Intrinsic motivation can be about caring for the job, giving the job a chance to learn something new, and the job can attract interest. Then extrinsic motivation can be the need of money, work for getting paid, and working because of encouragement from the family.

4. For other researchers related to this research, there are still opportunities to develop models in different settings by expanding the number of samples and research locations, so that broader generalizations can be made.

\section{BIOGRAPHY}

Fathurrohman, Pupuh dan Aa Suryana. 2012. Penyuluh pertanian Profesional. Bandung: PT Refika Aditama.

Gibson, James L. John M. Ivancevich dan James H. Donnelly, Jr. 2007. Organizations. McGraw- Hill Companies Inc. Boston.

Gering, Supriyadi dan Triguno. 2001. Budaya Kerja Organisasi Pemerintah. Jakarta

Hasibuan, Malayu S.P, 2005. Manajemen Sumber Daya Manusia, Jakarta: Penerbit Bumi Aksara.

Martono, Nanang. 2010. Statistik Sosial Teori dan Aplikasi Program SPSS. 
Edisi 1 pertama.Yogyakarta:Gaya Media.

Marzuki, Sukarno, 2002. Analisis Pengaruh Perilaku Kepemimpinan terhadap Kepuasan Kerja dan Kinerja Account : Studi Empirik pada Kantor Cab BRI di Wilayah Jawa Timur, Tesis, Program Pasca Sarjana Magister Manajemen Universitas Diponegoro (tidak dipublikasikan)

Marwansyah. 2010. Manajemen Sumber Daya Manusia. Edisi Kedua. Bandung: Alfabeta.

Mas'ud, Fuad. 2004. Survai Diagnosis Organisasional Konsep dan Aplikasi. Semarang: Badan Penerbit Universitas Diponegoro.

Ndraha, Taliziduhu. 2005. Budaya Organisasi, Ed 2, Jakarta, PT. Rineka Cipta.

Nurgiyantoro, Burhan. 2000. Teori Pengkajian Fiksi. Yogyakarta : Gajah Mada University Press Gramedia.

Rivai, Veithzal. 2008. Kepemimpinan dan Perilaku Organisasi. Edisi Kedua. Jakarta: PT RajaGrafindo Persada.

Santoso, Singgih. 2001. Buku Latihan SPSS Statistik Parametrik. Cetakan ke-1. Jakarta: PT Elex Media Computindo.

Sugiyono. 2012. Metode Penelitian Bisnis. Bandung, Alfabeta.

Sutrisno, Edy. 2011. Manajemen Sumber Daya Manusia. Jakarta: Kencana Prenada Media Group.

Sudjana, 2003. Metode Statistika,

Bandung: Rineka Cipta.

Stoner, freeman. 1992. Manajemen edisi keempat, jilid 1, alih bahasa Benyamin Molan, Intermedia.

Undang-undang No. 16 tahun 2006 tentang Sistem penyuluhan Pertanian, Perikanan dan Kehutanan.
Wibowo. 2012. Manajemen Kinerja. Edisi Ketiga. Jakarta: PT RajaGrafindo Persada.

Widiyati, Kurnia. 2000. "Analisis produktivitas tenaga kerja dan faktor yang mempengaru hinya di PT. Saung Mirwan, Cisarua, Bogor." Skripsi. Fakultas Teknologi Pertanian IPB. Bogor. 